\title{
HUBUNGAN KETERLIBATAN IBU DAN SELF-COMPASSION PADA ORANG TUA ANAK BERKEBUTUHAN KHUSUS
}

\author{
Mauna* \\ Savira Prameswari*** \\ *Fakultas Pendidikan Psikologi, Universitas Negeri Jakarta \\ **Fakultas Pendidikan Psikologi, Universitas Negeri Jakarta
}

DOI: $\underline{\text { https://doi.org/10.21009/JPPP. } 082.06}$

\author{
Alamat Korespondensi: \\ saviraprameswari08@gmail.com
}

\begin{abstract}
This study aims to look at the relationship between maternal involvement and self-compassion in parents of children with special needs. Maternal involvement is defined as maternal involvement in aspects of all child's life seen from two different domains, namely affective and behavior. Self-compassion is the ability of someone who can give attention and kindness to themselves when facing difficulties in life. Researchers use quantitative methods with a psychological scale. Mother Involvement was measured using's the Nurturance Mothering Scales \& Mother Involvement Scale developed by Finley \& Schwartz, and the self-compassion was measured by Self-compassion Scale developed by Neff. The sample used was 165 people. Sampling uses non probability sampling. Method of data analysis in testing multiple hypotheses using correlation techniques. The results showed a significant relationship between maternal involvement with self-compassion with a value of $r=0.041$ $<p=0.05$, and a significant relationship between maternal involvement reported with self-compassion with a value of $r=0.022<p=0.5$. The results of the study of the involvement of the desired mother with selfcompassion showed no significant relationship, with a value of $p>0.05$.
\end{abstract}

Keywords

Mother involvement, self-compassion, parents of special needs

\section{Pendahuluan}

Bagi sebagian besar pasangan yang sudah menikah pada umumnya menghendaki kehadiran seorang anak untuk membentuk keluarga yang sempurna. Anak yang terlahir dengan keadaan sehat lahir dan batin adalah dambaan semua orang tua. Sayangnya, tidak semua anak dapat dilahirkan dalam keadaan normal. Beberapa diantaranya memiliki keterbatasan baik secara fisik maupun psikis sehingga mereka memiliki kebutuhan yang berbeda. Anak yang memiliki kebutuhan berbeda ini disebut anak berkebutuhan khusus

Suran \& Rinzo (dalam Anggreni \& Valentina, 2015) menyatakan bahwa anak berkebutuhan khusus adalah anak yang terlahir dalam keadaan kurang sempurna secara fisik, psikologis, kognitif, ataupun sosial dan yang menyebabkan mereka terhambat dalam mencapai tujuan atau kebutuhan secara maksimal. Anak berkebutuhan khusus di klasifikasikan menjadi anak yang mengalami gangguan belajar, anak dengan pemusatan perhatian dan hiperaktif (ADHD), tunalaras atau retardasi mental, autis, anak yang mengalami gangguan komunikasi, tunarungu, tunanetra, tunaganda, tunadaksa, tunagrahita, dan anak berbakat atau gifted.

Berdasarkan data Biro Pusat Statistik (BPS) pada tahun 2009, jumlah anak berkebutuhan khusus menncapai 1,48 juta jiwa dan jumlah anak berkebutuhan khusus yang berusia 5-18 
tahun.berjumlah 317.016 anak (Rudiana, 2018). Dikutip dari health.detik.com, pada tahun 2013, jumlah anak berkebutuhan khusus mencapai 1,5 juta anak. Dikutip dari Kementrian Pendidikan dan Budaya (kemendikbud.go.id), jumlah ini kembali meningkat pada tahun 2017 yaitu sebanyak 1,6 juta anak.

Mengasuh anak berkebutuhan khusus berbeda dengan mengasuh anak normal lainnya. Hal ini dikarenakan untuk mengurus anak berkebutuhan khusus membutuhkan waktu serta biaya yang tinggi, sehingga orang tua merasa bahwa mereka memiliki beban yang cukup berat. Beban yang berat ini menimbulkan reaksi-reaksi yang cenderung negatif.

Hasil penelitian yang dilakukan oleh Anggreini (2013), terdapat beberapa hasil terkait dengan reaksi-reaksi negatif orang tua terhadap anak berkebutuhan khusus. Sebanyak $34,48 \%$ orang tua merasa kecewa karena kondisi anaknya tidak sesuai dengan harapannya, kemudian sebesar $44,82 \%$ orang tua merasa bersalah dan kurang berhati-hati saat mengandung anaknya sehingga anaknya mengalami kondisi berkebutuhan khusus, dan sebanyak $58,62 \%$ orang tua merasa malu dengan kehadiran anak berkebutuhan khusus.

Beberapa reaksi-reaksi negatif yang dialami oleh orang tua anak berkebutuhan khusus cenderung dipengaruhi oleh pola asuh ayah dan ibu sebelumnya. Penelitian menemukan bahwa pola asuh orang tua yang buruk di masa lampau berkaitan dengan tingginya emosi-emosi negatif seperti kemarahan, depresi, dan kecemasan. Beberapa orang melaporkan bahwa mereka yang memiliki hubungan buruk dengan keluarganya, cenderung memiliki kepercayaan diri dan kesejahteraan emosi yang rendah (Mallers, et.al, 2010).

Orang tua anak berkebutuhan khusus perlu untuk mengurangi emosi-emosi negatif dengan memiliki kemampuan self-compassion. Self- compassion adalah sikap yang dapat memberikan perhatian dan kebaikan terhadap diri sendiri saat menghadapi kesulitan dalam hidup maupun terhadap kekurangan dalam dirinya serta memiliki pengertian bahwa penderitaan, kegagalan, dan kekurangan merupakan bagian dari seseorang (Neff, 2003b). Self-compassion sebagai upaya untuk "merangkul" emosi negatif dan dapat mengubah emosi negatif menjadi emosi positif.
Self-compassion menurut Neff (2003) memiliki 3 aspek, yaitu self-kindness, common humanity, mindfulness. Self-kindness adalah berbuat baik kepada diri sendiri dengan cara memberikan perhatian serta dukungan untuk diri sendiri. Common humanity adalah sikap dimana seseorang dapat berfikir bahwa kesalahan yang dilakukannya merupakan hal yang wajar, sehingga tidak terlalu larut dalam rasa bersalah. Mindfulness adalah kemampuan untuk menyeimbangi diri disaat berada pada kondisi yang tertekan atau sulit. Setiap aspek memiliki sifat atau sikap yang bertolak belakang, yaitu self-judgement atau kritik terhadap diri sendiri, isolation atau isolasi, dan over identification.

Kemampuan self-compassion pada seseorang tidak terlepas dari bagaimana orang tua terlibat, salah satunya ialah ibu. Self-compassion akan berkembang jika ibu terlibat langsung dalam pengasuhan dan memberikan rasa afeksi seperti kehangatan dan kepedulian. Hubungan keterlibatan ibu-anak secara signifikan berkaitan dengan tingkat emosi pada anak. Terlepas dari perbedaan jenis kelamin anak, hubungan ibuanak yang berkualitas baik atau tinggi akan menghasilkan tingkat stres yang rendah di masa dewasa, sehingga keterlibatan ibu sangatlah penting bagi tumbuh kembang anak (Mallers, et.al, 2010).

Keterlibatan ibu adalah sejauh mana ibu terlibat dalam berbagai aspek kehidupan anak seperti bermain atau berbagi kegiatan bersama, memberi perhatian, membangun rasa persahabatan atau pertemanan dengan anak, mengajarkan anak belajar untuk mengembangkan intelektual anak, dan lain-lain Finley (2008) mengemukakan bahwa dalam hal pengasuhan, ibu dan ayah memiliki fungsi struktural pengasuhan yang sama, meskipun peran yang dilakukan oleh ayah dan ibu berbeda.

Menurut Day \& Padila Walker (dalam Profe \& Wild, 2015), keterlibatan ibu dalam pengasuhan memberikan hasil atau dampak yang terkait dengan harapan dan perilaku prososial pada anak. Selain itu, keterlibatan ibu juga cenderung memfokuskan pada keterampilan membangun hubungan, rasa hangat serta dukungan, dan perilaku empatik sehingga memicu anak untuk meniru dan mengaplikasikannya ke dalam hubungan mereka sendiri (Domitrovich \& Bierman dalam Profe \& 
Wild, 2015).

Hasil penelitian terkait self-compassion dilakukan oleh Neff dan McGehee pada tahun 2009 menyatakan bahwa self-compassion pada anak akan berkembang jika anak memiliki ibu serta keluarga yang memberikan kehangatan dan rasa peduli pada anak. Sebaliknya, jika ibu dan keluarganya tidak memberikan kehangatan kepada anak maka anak mengembangkan selfcompassion yang juga buruk dan cenderung mengkritik dirinya sendiri ketika mengalami masalah.

Oleh karena itu, peneliti tertarik untuk melakukan penelitian terkait hubungan antara keterlibatan ibu dengan self-compassion pada orang tua yang memiliki anak berkebutuhan khusus. Berdasarkan pemaparan di atas, maka rumusan masalah pada penelitian ini adalah "Hubungan Keterlibatan Ibu dan Self-Compassion pada Orang Tua Anak Berkebutuhan Khusus". Hipotesis yang digunakan dalam penelitia ini adalah terdapat hubungan antara keterlibatan ibu dan self-compassion pada orang tua anak berkebutuhan khusus.

\section{Metode Penelitian}

Penelitian ini termasuk dalam penelitian kuantitatif. Populasi dalam penelitian ini adalah orang tua yang memiliki anak berkebutuhan khusus yang bertempat tinggal di Jakarta. Kriteria subjek pada penelitian ini adalah orang tua anak berkebutuhan khusus dan berdomisili di Jakarta. Teknik sampling yang digunakan dalam penelitian ini adalah non probability sampling. Teknik non probability sampling yang digunakan ialah purposive sampling. Jumlah sampel pada penelitian ini ialah 165 orang.

Penelitian ini menggunakan metode kuesioner sebagai cara untuk mendapatkan data. Kuesioner yang diberikan menggunakan adalah Nurturant Mothering Scales (NMS) dan Mother Involvement Scale (MIS). Mother Involvement Scale ini kemudian dibagi lagi menjadi Reported Mothering Scale dan Desired Mothering Scale. Intrumen ini dibuat oleh Finley berdasarkan alat ukur keterlibatan ayah dengan mengganti kata "ayah" menjadi "ibu" dan instumen Self-Compassion Scale (SCS) yang dibuat oleh Neff untuk mengukur selfcompassion.

\section{Hasil Penelitian dan Diskusi}

Sebelum instrument dapat digunakan, peneliti melakukan proses validitas dan reliabilitas terhadap instrumen yang digunakan. Instrumen Self-Compassion Scale memiliki reliabilitas sebesar 0,80, kemudian untuk instrumen Nurturant Mothering Scale memiliki reliabilitas sebesar 0,93, dan untuk instrumen Reported Mothering Scale dan Desired Mothering Scale memiliki reliabilitas 0,97

Selanjutnya, dilakukan pengolahan data dengan menggunakan aplikasi SPSS. Untuk selfcompassion, diperolah nilai minimum 46 dan nilai maksimum sebesar 98. Kemudian, skor ratarata atau mean pada instrument ini ialah 71,8 dengan standar deviasi 9,53.

Skor self-compassion yang didapat dikategorikan menjadi dua kategori, yaitu rendah dan tinggi. Berdasarkan hasil pengolahan data yang dilakukan sebanyak 19 orang atau $11,5 \%$ memiliki self-compassion dan sebanyak 146 orang atau $88,5 \%$ memiliki self-compassion yang tinggi.

Kemudian, untuk hasil pengolahan data nurturant mothering scale atau keterlibatan ibu afektif memiliki nilai minimum sebesar 12 dan nilai maksimum sebesar 45 . Kemudian, nilai tengah atau mean pada instrument ini ialah 37,18 dan nilai standar deviasi sebesar 6,39.

Kategorisasi skor pada keterlibatan ibu afektif dibagi menjadi tiga, yaitu rendah, sedang, dan tinggi. Berdasarkan hasil pengolahan data yang dilakukan, sebanyak 5 orang atau $3 \%$ memiliki keterlibatan ibu segi afektif yang rendah, kemudian sebanyak 34 orang atau $20,6 \%$ memiliki keterlibatan ibu segi afektif sedang, dan sebanyak 126 orang atau 76,4\% memiliki keterlibatan ibu segi afektif yang tinggi.

Instrumen selanjutnya yaitu reported mothering scale atau keterlibatan ibu yang dilaporkan memiliki nilai minimum sebesar 20 dan nilai maksimum sebesar 100. Nilai tengah pada instrument ini adalah 81,67 dan standar deviasi sebesar 15,04.

Kategorisasi skor pada keterlibatan ibu yang dilaporkan dibagi menjadi tiga, yaitu rendah, sedang, dan tinggi. Berdasarkan hasil pengolahan data yang dilakukan sebanyak 5 orang atau 3\% berada pada kategori yang tinggi, kemudian sebanyak 42 orang atau $25,5 \%$ berada kategori

Jurnal Penelitian dan Pengukuran Psikologi, Vol. 8 , 2 , Oktober 2019 
sedang, dan sebanyak 118 orang atau 71,5\% memiliki kategori tinggi.

Instrumen terakhir yaitu desired mothering scale atau keterlibatan ibu yang diinginkan memiliki nilai minumun sebesar 40 dan nilai maksimum sebesar 100. Nilai tengah atau mean pada instrument ini ialah 75,77 dan standar deviasi sebesar 73. Pada instrument ini dibagi menjadi tiga ketegorisasi sesuai dengan kategorisasi yang dibuat oleh Finley, yaitu kurang terlibat, cukup terlibat, ingin lebih terlibat. Pada instrument ini, 165 responden berada pada kategori cukup terlibat.

Kemudian,dilakukannya uji korelasi untuk melihat apkah terdapat hubungan antar variabel dan diperoleh bahwa terdapat hubungan yang signifikan antara self- compassion dengan keteribatan ibu segi afektif dan keterlibatan ibu yang dilaporkan. Self-compassion dan keterlibatan ibu yang afektif memiliki nilai $\mathrm{p}=$ $0,041<0,05$, dan self-compassion dan keterlibatan ibu yang dilaporkan memiliki nilai $\mathrm{p}$ $=0.022<0.05$. Hal ini berarti semakin tinggi keterlibatan ibu, maka semakin tinggi juga selfcompassion pada orang tua anak berkebutuhan khusus, sebaliknya semakin rendah keterlibatan ibu maka self-compassion pada orang tua anak berkebutuhan khusus juga akan rendah.

Untuk self-compassion dan keterlibatan ibu yang diinginkan tidak terdapat hubungan yang signifikan. Hal ini dikarenakan nilai $\mathrm{p}$ yang dihasilkan yaitu 0,375 lebih besar dari nilai $\alpha$ yaitu 0,05 .

Berdasarkan data di atas, dapat disimpulkan bahwa ibu berperan penting dalam perkembangan self-compassion pada anak diasumsikan karena ibu cenderung terlibat dalam hal afeksi seperti memberikan rasa kepedulian, perhatian, rasa pertaman, dan kehangatan, dimana hal tersebut dapat mempengaruhi perkembangan selfcompassion pada seseorang. Hal ini sesuai dengan hasil penelitian yang dilakukan oleh Han \& Jun pada tahun 2013 terkait keterlibatan ibu dan ayah pada perkembangan anak. Penelitian tersebut menyatakan bahwa ibu cenderung terlibat dalam hal afektif dibandingkan dengan ayah

Hubungan keterlibatan ibu-anak secara signifikan berkaitan dengan tingkat emosi pada anak. Hubungan antara ibu dengan anaknya berfungsi sebagai fondasi yang menonjol dalam mengembangkan rasa aman dan kesejahteraan emosi pada anak secara umum, terlepas perbedaan dari jenis kelamin anak.

Responden pada penelitian ini sebagian besar memiliki self-compassion yang tinggi. Hasil data penelitian diatas menemukan bahwa responden yang mengikuti penelitian ini memiliki selfcompassion yang tinggi sebesar $88,5 \%$. Responden yang memiliki self-compassion yang tinggi memiliki keterlibatan ibu yang juga tinggi. Hal ini dibuktikan dengan responden yang sebagian besar memiliki keterlibatan ibu yang tinggi, baik secara keterlibatan ibu yang afektif, keterlibatan ibu yang dilaporkan, dan keterlibatan ibu yang diinginkan

\section{Kesimpulan}

Berdasarkan hasil yang sudah diuraikan, terdapat hubungan yang signifikan antara selfcompassion dengan keterlibatan ibu afektif dan keterlibtan ibu yang dilaporkan. Kemudian, tidak terdapat hubungan yang signifikan antara selfcompassion dengan keterlibatan ibu yang diinginkan.

\section{Daftar Pustaka}

Anggreni, Ni Made Diah Ayu, Tience Debora Valentina. (2015). Penyesuaian orang tua dengan anak down syndrome. Jurnal Psikologi Udayana.

Anggraini, Rizma Rizki. (2013). Persepsi orang tua terhadap anak berkebutuhan khusus (deskriptif kuantitatif di sdlb.n 20 nan balimo kota solok). Jurnal Ilmiah Pendidikan Khusus.

Finley, Gordon E, et.al. (2008). Perceived paternal and maternal involvement: factor structure, mean differences, and parental roles. Fathering. Vol 6. No 1.

Han, Yeoh Si, Woo Pei Jun. (2013). Parental involvement in child's developoment

Jumlah anak berkebutuhan khusus. Retrived From: https://health.detik.com/anak-danremaja/d- 2306161/jumlah-anakberkebutuhan-khusus-di- indonesiadiperkirakan-42-juta 
Mallers, et.al. (2010). Perceptions of childhood relationships wih mother and father: daily emotional and stress experiences in adulthood. Dev Psychol

Neff, Krstin D. (2003). Self-compassion: an alternative conceptualization of a healthy attitude toward oneself. Psychology Press.

Neff, Kristin D, Pittman McGehee. (2009). Selfcompassion and psychological resillience among adolescents and young adults. Self and Identity. Vol. 9: 3.

Profe, Wade, Lauren G Wild. (2015). Mother, father, and grandparent involvement: associations with adolescent mental health and substance use. Journal of Family Issues.
Rusdiana. (2018). Hubungan antara dukungan keluarga dengan penerimaan diri pada orang tua yang memiliki anak berkebutuhan khusus (ABK) di samarinda. Psikoborneo.

Siswa penyandang disabilitis berdasarkan provinsi.

Retrivied from https://lokadata.beritagar.id/chart/previe w/siswa-penyandang-disabilitasberdasarkan-provinsi-1520847488 